\begin{abstract}
"Mircea cel Batran" Naval Academy Scientific Bulletin, Volume XX - 2017 - Issue 1
The journal is indexed in: PROQUEST / DOAJ / Crossref / EBSCOhost / INDEX COPERNICUS / DRJI / OAJI I

JOURNAL INDEX I I2OR / SCIENCE LIBRARY INDEX / Google Scholar / Academic Keys/ ROAD Open Access I Academic Resources / Scientific Indexing Services / SCIPIO / JIFACTOR
\end{abstract}

\title{
THE EFFECTS OF FDI ON ECONOMIC GROWTH IN EUROPEAN UNION
}

\author{
Cristian Dragoș TEODORESCU ${ }^{1}$ \\ ${ }^{1} \mathrm{PhD}$. Assoc. Prof. Department of Informatics, Economic Cybernetics, Finance and Accounting, \\ Faculty of Economic Sciences, Petroleum- Gas University of Ploiesti, Bulevardul București nr. 39, \\ cteodorescu@upg-ploiesti.ro
}

\begin{abstract}
Foreign direct investment (FDI) is support the economic development of a country, influencing the economy and leading to increased productivity and increased the competitiveness. In the same time, FDI have a decisive contribution to increasing labor's employment, technological development and the changing of ownership structure. Starting from theoretical studies and empirical analyzes on FDI and economic growth, this study addresses the impact of FDI on economic development in the European Union.
\end{abstract}

Key words: FDI, economic growth, GDP, European Union

JEL Classification : F21, F23, F63, O11, O52.

1.Introduction.

Within economic affairs, investments represent the generator element that makes them be born, also to pursue and develop. Foreign investment will complete the necessary internal resources and develop the competitive factors of production. This can be ensured, however, only within a proper investment climate, based on transparent, consistent and competitive policies and reforms in order to attract foreign capital. Foreign direct investment is one of the key factors of globalization of capital. FDI generates a variety of effects on the host economies, among which the most important are related to increasing labor productivity through transfer of know-how, technology, favoring the same time, technological progress and long-term economic growth, thereby improving the standard of living. At the macroeconomic level, the main positive impact is the standard of living, reflected by higher disposable incomes, decreasing unemployment, diversification of products and services, as well as increasing the quality, etc. Meanwhile, FDI mainly generates negative effects on the social and natural aspects highlighted by specialists. So, the impact of FDI on the host economy is different from state to state, depending on the existing economic, political, social, and the degree of penetration of foreign capital.

\section{THEORETICAL ISSUES ON FDI}

The foreign investments are o main part of International flows that reflects the purpose entity, private or legal person residing in a country to obtain a short term or long term interest, in a company resident in another country. FDI represent methods how an economic agent makes investments in other countries: buying bonds on foreign markets; establish a company or open a branch in another country; grants credit to a foreign economic entity; acquiring a foreign company or merging with it. Foreign investments involve the existence of at least two undertakings: business issuer and trader receiver. Economic relations established between the issuer and the receiver lead to the emergence and existence of two types of investment: direct investment and indirect investment. Direct investment issuer if the agent can control and make decisions on the activities of agent receiver, otherwise we can speak of an indirect investment. In the literature, the issue of FDI has been and is widely debated. What is FDI? Foreign investments can be defined as "transfers of capital from one country to another" [2]. Another Romanian author [22] defines investment as "the contribution that the association between a foreign party, generally a transnational company, and a state will bring to the state' economy" . Regardless of the method by which the foreign investment is realized (starting a business, open a branch, acquisition of foreign companies, purchasing shares / bonds, etc.), foreign investment can be direct, when the issuer has the option to make managerial decisions and control over investment and foreign portfolio investment, which are purely financial investments. According to the United Nations Trade and Development Organization, long-term relationship exists between the direct investor and the direct investment involves direct and significantly participation at the helm of the company and includes both the initial transaction and subsequent transactions (UNCTAD, 2002, p. 291) .Another definition said that,, Foreign direct investment involves a long-term investment relationship between a resident entity and a nonresident entity; it usually implies that the investor exerts a significant influence in the management of the investee company. " [27].

There are a number of determinant factors in attracting FDI, explain by the Dunning's model, the model of gravity and the locality theory. Dunning argues in his model called eclectic paradigm (OLI) that internationalization of production is achieved when the company has three types of advantages: ownership advantages (specific to company), location advantages (specific to host country) and internalization advantages. Given the fact that possession of 
these advantages involves a minimum level of development of source, John Dunning analyzed FDI flows in a dynamic relation, trying to explain the change in the level and structure of FDI receipted and generated by a country, depending on the development's level. Dunning started from the assumption that with economic development, measured by GDP / capita, a country changes its investment position once the stock of FDI outputs and stock of FDI received. [11]. The gravity model is an application of Newton' s law in the economy, being used for the first time by Tinbergen [24], for modeling and optimize the bilateral trade. In 1966, Linnemann[19] argued that the size of bilateral international trade flows depends on three factors: the request of the importer, the exporter's offer and the business cost. His model shows trade flows from a point of origin to destination on terms dictated by fender factors from the point of origin, demand factors from the point of destination and stimulating/stopping factors of this specific flow. This model has undergone successive improvements by adding other variables: the infrastructures were introduced by [18] by crosssection analysis, while real rates of exchange were introduced into the model by [3]. According to the classical theory of location, economic integration leads to specialization of regions according to available inputs, ie according to their comparative advantage. Although certain regions justify specialization, comparative advantage's theory cannot provide explanations for the concentration of economic activities in certain areas. Scotchmer and Thisse[23] showed that to explain the differential distribution of economic activities in areas with similar equipment, must be taken into account the increasing yields of scale. Krugman and Venables [14] analyzed the effect of the combination of low business costs and transport costs to choose a company location. Krugman model explains the effect of changing the location of a business activity from one region to the other, to the balance regional development. The emergence of a new business in a region causes additional pressure on product market and the labor market. The decision to invest in a particular country is based on a thorough analysis of economic, social and political factors, but also a number of incentives of foreign investors such as establishing a strong position in the national market, gaining access to a new regional market, access to natural and human resources, access to research resources, access to factors of production with a real low cost, in order to achieve a number of benefits, but also a higher level of development. FDI major effects on host countries are related to increasing labor productivity through transfer of know-how, technology, management skills and marketing by promoting technological progress and economic growth in the long term in emerging countries. The economic literature shows the impact of FDI on host countries through FDI effects: direct / indirect and positive / negative especially on domestic firms. The direct effects are: employment, increase the volume of commercial transactions, capital formation. Although for some countries these are the most important effects of FDI (especially poor countries with high rates of unemployment) there are also some indirect effects such as technology transfer and managerial skills to local firms (so-called demonstrative effect). This transfer is regarded as an externality related to a country's productivity and researchers have shown that these indirect effects are the main reasons to attract foreign investors, especially in the developing states by implementing technological progress in the economy or certain industries. The FDI impacts can be positive or negative. Positive macroeconomic implications are related mainly to economic growth, stimulating domestic investment, increasing capital investment, increasing budget revenues by increasing tax base. The main effect is economic growth, which is performed differently depending on the form of FDI. In the case of greenfield investments, creating new production capacities, new jobs, lead to economic growth. In the case of privatization, the positive effects occur when economic activity is efficient and there is a strengthening of its competitiveness, with long-term effects on businesses. Typically, direct investments have positive effects at the country's level implementation, but it is not excluded occurrence of a negative macroeconomic and / or sectorial impact. These short term effects are relates mainly to:

$\square$ increased imports, especially of machinery and equipment needed for the investment financed by foreign investors, leading to deterioration of the trade balance;

$\square$ rising unemployment following the restructuring of privatized enterprises

$\square$ negative impact on budget revenues, caused by the granting of tax incentives to foreign investors. In conclusion, the impact of FDI on the host economy is different from country to country, according to the existing concrete economic, social and political conditions, and the degree of penetration of foreign capital. Macroeconomics can be searched using specific concepts such as economic growth, expansion and recession, economic development and socio-economic underdevelopment, economic progress and regress etc. Currently, nations considered economic growth as a synthetic expression of the 
opportunity for a better life and therefore represents a major objective of macroeconomic policy. More broadly, economic growth means rising evolution of economic size in a particular spatial and temporal framework. In a narrow sense, economic growth is seen as a positive development of the national economy upward. Economic growth is seen as a complex process that takes place in an economy or region in a given period, and expressing usually factors or resources multiplication capacity of that economy to provide various economic goods, having favorable effects in economic and social life. Economic growth requires increased allocation of resources to increase capital goods, for education and scientific research etc. The cost of economic growth is the effort, consumption of growth factors of production required to achieve a certain ratio of total GDP and GDP per capita. Unlike a static economy, a dynamic economy (growing) can consume more and at the same time, can enhance the ability to produce more in the future. The resulting economic growth due to resource allocation for investments depend upon the efficiency with which these resources are used and the ability of the economy and population to assimilate the changes inherent in such a process. A rapid growth rate requires rapid adjustments involving personnel costs of those who are affected negatively (unemployment, environmental pollution, social dislocation, etc.). These costs, however, are judged in relation to the benefits it can bring the long-term economic growth. A sustained increase in GDP, accompanied by an increase in productivity and wages, was an important aspect of raising the standard of living in industrialized countries, as well as the exit from poverty. Rapid growth or economic downturn are felt by the entire population, but the effects are unevenly distributed. Economic growth is a necessary but not sufficient to increase income of the poor. It contributes to poverty reduction if it leads to an increase in employment and wages of the poor and if public resources are used towards human development. Otherwise, economic growth widening income inequalities and even lead to a reduction of revenues of certain categories of the population.

3. Literature review.

There are a lot of studies analyzing the effects of foreign direct investments on economic growth. In a study covering 84 developed and developing countries for the period of 1970-1999, [17] found a strong relationship between FDI and growth. Identical results, but strongly related to human capital, infrastructure, financial market development and trade policy of the target country were obtained by [15] who investigate the relationship between international technology spillovers, the host country's absorptive capability and endogenous economic growth and revealed that long-run growth arose from improvements in absorptive capability and higher human capital stocks, while the relationships between openness, the technology gap and the steady-state growth rate were uncertain.

According to [13] their study among 25 OECD member countries and 20 Non-OECD countries covering the years of 1970-2004 suggest that FDI had positive effects on economic growth on OECD countries whereas it had a non-linear effect on growing countries. [8] found a hump-shaped relationship between FDI and growth according to their research in 11 Central and Eastern European countries (CEECs) during the period of 1996-2003.Analyzing the annual data for 37 countries during 1970-2002 [16] find a direct and long relationship among FDI, financial development, and economic growth, while [12] highlighted the role of infrastructure as one of the most important determinants for enhancing the efficiency of FDI. According to this study, the authors stated that there is a direct relationship among the degree of technology spillover and FDI inflows but also a conditional connection between the technology gap and the country's infrastructure level.[10] assert that FDI has a positive impact on economic growth in developing countries, based on the FDI growth hypothesis for 28 developing countries.

[5] analyses the relationship between the inflows of FDI and economic growth on the basis of the panel data, covering 72 developed and developing economies, the results showing a weak connection between the FDI inflows and economic growth in analyzed countries.

The inflow of foreign direct investments stimulates internal investments. As a result of investments in infrastructure (e.g. roads and factories), foreign investors may help reduce the distance to highly developed countries [21]. From this perspective, the FDI inflows can lead to the increase of productivity of all companies, not only those that directly receive foreign capital [20]. [4] prove that the inflow of foreign direct investments involves the inflow of technology to the host country which leads to higher growth of host country, but the sizes of these benefits depend on human capital resources available in the host country. Other studies Blomstrom, Lipsey, and Zejan (1994) proved that there are no evidence that highly educated workers can contribute to a positive growth effect of FDI, but the positive effect is seen when the country is sufficiently rich.

Many empirical studies studying the role of FDI in a host country suggest that the inflows are an important source of capital, involving new labor 


\section{"Mircea cel Batran" Naval Academy Scientific Bulletin, Volume XX - 2017 - Issue 1 The journal is indexed in: PROQUEST / DOAJ / Crossref / EBSCOhost / INDEX COPERNICUS / DRJI / OAJI I JOURNAL INDEX I I2OR / SCIENCE LIBRARY INDEX / Google Scholar / Academic Keys/ ROAD Open Access I Academic Resources / Scientific Indexing Services / SCIPIO / JIFACTOR}

force, import technology to the host country, which leads then to a higher growth of the economy [6]. Other studies [1], [7] and [9] argue that only countries with a relatively well-developed financial market system has an economic growth as a result of FDI inflows.
4. Study case - FDI flows and the economic growth in European Union in 2004-2015 As shown above, economic growth is the main result of FDI flows. Thus, we analyzed the annual GDP growth rate in 2005-2015.

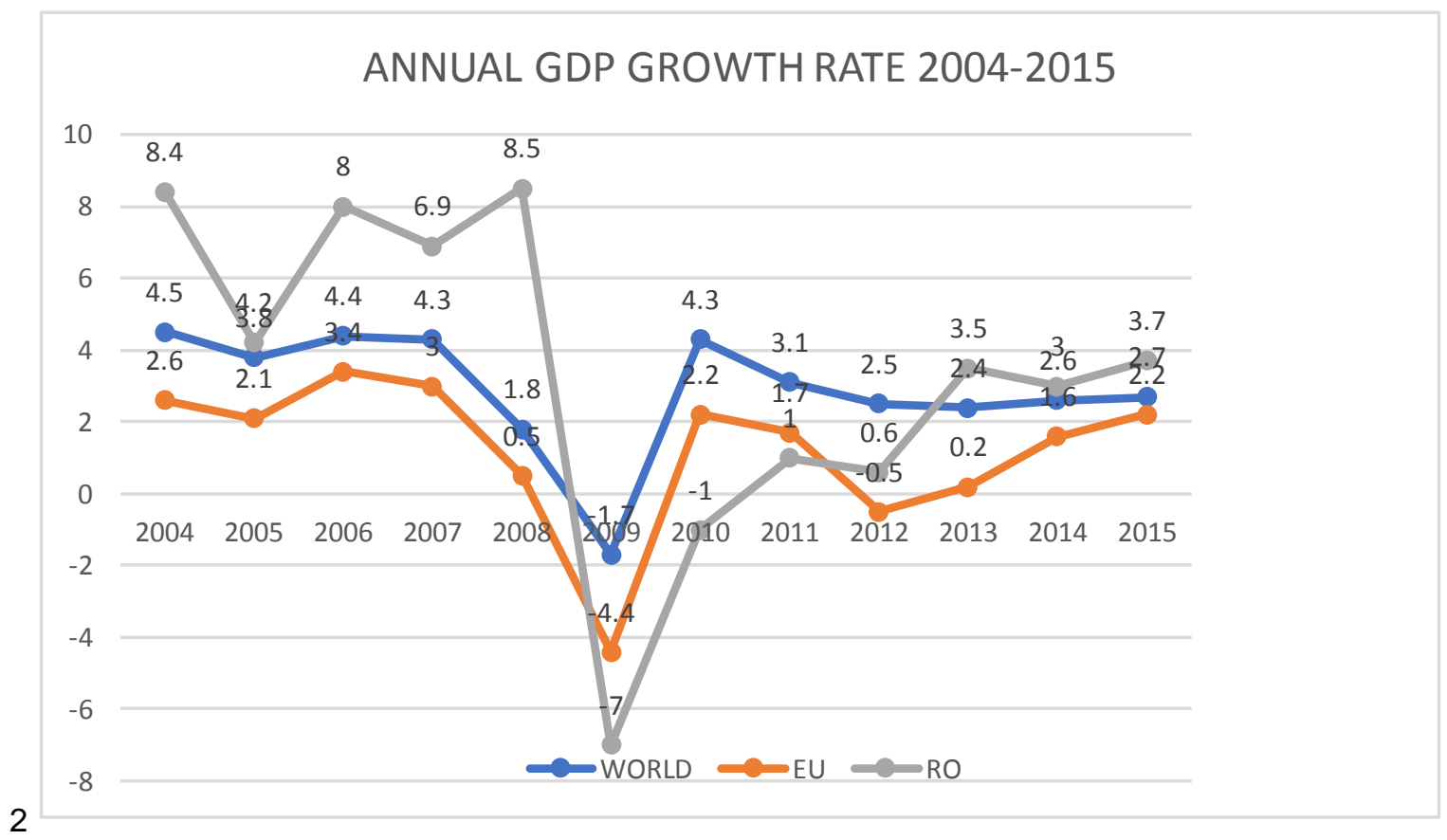

Source: author calculations after World Bank Databases,

http://data.worldbank.org/indicator/NY.GDP.MKTP.KD.ZG

A first observation relates to the fact that during the analyzed period, annual GDP growth rate showed a similar trend at global level, at EU level, but also in our country. Analysis of annual GDP growth rates can be divided into three distinct periods: the period 2004 - 2007, characterized by increasing GDP, between 2008-2009 economic crisis and post-crisis period and 2010 - 2015, characterized by annual average increase around $3 \%$. In the period 2004-2007, global annual growth rate ranged from 4.3 to $4.5 \%$ higher than the EU countries rate, where the annual growth rate did not exceed $3.4 \%$ (2006). An atypical evolution recorded Romania, where the maximum level was recorded in 2004 (8.4\%), followed by a fluctuating trend over the next three years.

The economic crisis of 2008-2009 resulted in a decrease of annual GDP growth rate sharply on the 3 segments analyzed. At global level there has been a contraction in annual GDP growth rates of over $3.5 \mathrm{pp}$, while in the $\mathrm{EU}$, the decrease was $4.9 \mathrm{pp}$. Romania recorded a sharp drop in annual GDP growth rates from 8,5 \%, in 2008 to $7 \%$ in 2009. Post crisis period has showed different rates of annual GDP growth. Globally there is an increase from the 2009 negative level of $4.3 \%$ in 2010 , after which annual GDP growth rate shows a linear decrease to $2.7 \%$ in 2015 .

EU has the same trend, an increase to $2.2 \%$ in 2010, followed by a decrease in 2011-2012, reaching an annual rate of GDP growth of $2.2 \%$ in 2015.

Evolution of the annual GDP growth rate in Romania is not within the European and global trends, our country registered a continuous increase during 2010-2015.

I noticed that in the analyzed period, there are two major points of inflection: 2009 which marks the minimum level for all regions except South Asia which recorded the lowest economic growth rate in 2008, and 2010 which marks a return to growth rates from the period before the economic crisis. Between 2005 - 2015 the FDI inflows flows have various evolutions. 


\begin{abstract}
"Mircea cel Batran" Naval Academy Scientific Bulletin, Volume XX - 2017 - Issue 1 The journal is indexed in: PROQUEST / DOAJ / Crossref / EBSCOhost / INDEX COPERNICUS / DRJI / OAJI I JOURNAL INDEX I I2OR / SCIENCE LIBRARY INDEX / Google Scholar / Academic Keys/ ROAD Open Access I Academic Resources / Scientific Indexing Services / SCIPIO / JIFACTOR
\end{abstract}

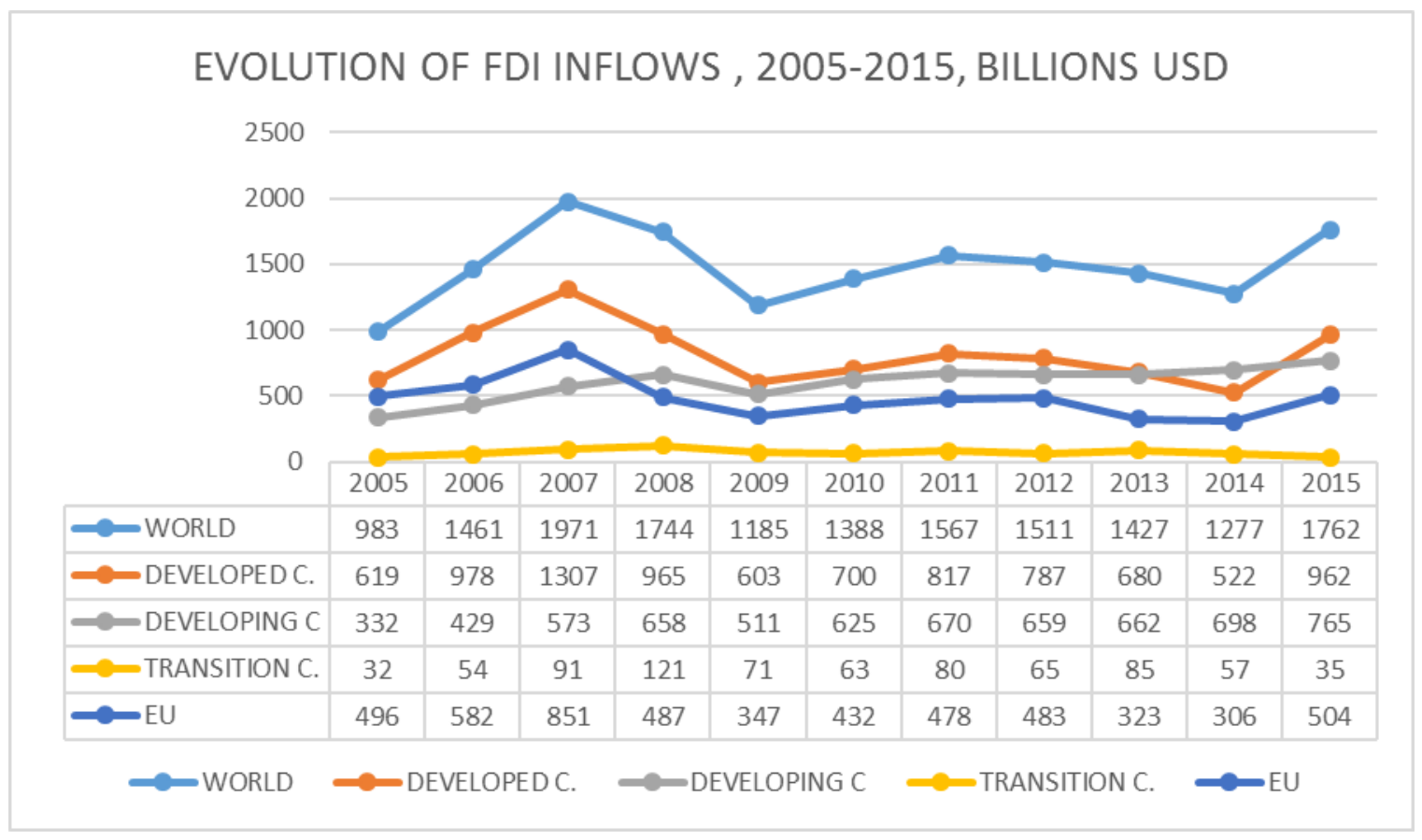

Source: UNCTAD, World Investment Report 2006, 2011 and 2016.

World FDI inflows have a divergent evolution, with an increase of $100.5 \%$ in the first 3 years of analysis, reaching the 2007 value of 1.971 trillion dollars, which is the maximum in period 2005 2015. In 2010-2012, economic recovery amid the global economic growth rate recorded before the crisis, there is a revival of international investment flows growing by over $27 \%$ in 2012 compared to 2009. In the following years, due to the slowdown in global economic growth, are registered an overall decrease in FDI inflows trend, so in 2014 it stands at only $65 \%$ of the level registered in 2007 , but an increase of $38 \%$ in 2015 compared to the previous year.

The structural analysis by types of countries, shows that developed countries, developing and transition economies have different evolutions, depending on global economic developments and regional or national objectives. Thus, developed countries have received on average over $54 \%$ of FDI inflows at global level. In 2007, FDI inflows reached their highest value for developed countries, while the minimum value of FDI inflows was reached during the crisis. Post crisis period is characterized by successive ups and downs of FDI inflows, registering a volume of FDI inflows in 2015 to $11 \%$ lower than 2007. Developing Countries received FDI inflows at an average percentage of $40.81 \%$ of total global flows. Foreign capital inflows to these countries increased by $130.42 \%$ during the period under review, due to the slow pace of economic growth in developed countries, due to the need of investors to find new investment opportunities or relocate businesses in developed countries due high costs. FDI inflows have had an upward trend, with two interruptions (2009 and 2012), the maximum level of FDI inflows being reached in 2015 (765 billion USD).

Regarding the transition economies, these countries attracts a small percentage of global FDI inflows (average 4.62\%). The maximum level was recorded in 2008 (US \$ 121 billion), followed by successive decreases of inflows, reaching 35 billions USD in 2015, representing more than a third of 2008.

EU received on average $32.68 \%$ of FDI inflows worldwide. The analyzed period is characterized by successive increases and decreases flows, recorded the maximum level in 2007 (851 billions USD) and reaching in 2015 a value of 504 billion USD, representing $59.2 \%$ of 2007 and being only 8 billions USD higher than 2005 value[28].

FDI inflows of the EU were influenced by changes in global and regional level. So in 2015 we have outlined a dual trend of FDI inflows. First direction is related to the states that have experienced reductions in FDI inflows, compared to 2007: Germany (down 65\%), Belgium, Spain (- 85\%) , Austria $(-87 \%)$, France $(-57 \%)$ and Bulgaria (83\%). There are EU member states that registered increases in FDlin 2015 compared to 2007 such as: Denmark (+ 572.7\%), Ireland (+ $316 \%$ ), and Member States registered increases in 2015 compared to 2010: France (+ 230.7\%), Netherlands ( +80 billion USD), Italy ( $+122.2 \%)$ [28]. It is interesting how it evolved TOP 5 countries on FDI inflows. 
"Mircea cel Batran" Naval Academy Scientific Bulletin, Volume XX - 2017 - Issue 1 The journal is indexed in: PROQUEST / DOAJ / Crossref / EBSCOhost / INDEX COPERNICUS / DRJI / OAJI I JOURNAL INDEX I I2OR / SCIENCE LIBRARY INDEX / Google Scholar / Academic Keys/ ROAD Open Access I Academic Resources / Scientific Indexing Services / SCIPIO / JIFACTOR

Table no.1 - Top 5 FDI Inflows Countries 2007 versus 2015

\begin{tabular}{|l|l|l|l|l|}
\hline 2007 & $\begin{array}{l}\text { FDI Inflows - } \\
\text { billions USD }\end{array}$ & Rank & 2015 & $\begin{array}{l}\text { FDI Inflows - } \\
\text { billions USD }\end{array}$ \\
\hline UK & 196 & 1 & IRELAND & 100 \\
\hline NETHERLANDS & 119 & 2 & NETHERLANDS & 73 \\
\hline FRANCE & 96 & 3 & FRANCE & 43 \\
\hline BELGIUM & 93 & 4 & UK & 40 \\
\hline GERMANY & 80 & 5 & GERMANY & 31 \\
\hline TOTAL TOP 5 & 584 & ----- & TOTAL TOP 5 & 287 \\
& & & & \\
\hline
\end{tabular}

SOURCE: author computation based on UNCTAD, World Investment Report 2012 and 2016

A first observation is that the value of FDI inflows to the first 5 Countries in 2015 represents $49.14 \%$ of FDI inflows in 2007, but individual values of the countries are in a significant drop in 2015/2007.TOP 5 composition is almost identical in the 2 years, the only move is the elimination of Belgium and Ireland appearance in 2015, even in leader position. The hierarchy suffered changes: Netherlands (2 rank), France (rank 3) and Germany (5 rank) maintains their positions, UK lose its leading position held in 2007 in favor of Ireland. Developed Economies are the main source of foreign capital, evolutions in these states, mainly in economic matters, strongly influencing the amount and structure of FDI outflows. From the chart below I noticed that during the reviewed period, FDI outflows have the same dynamics with FDI inflows.

\section{EVOLUTION OF FDI OUTFLOWS, 2005-2015, BILLIONS USD}

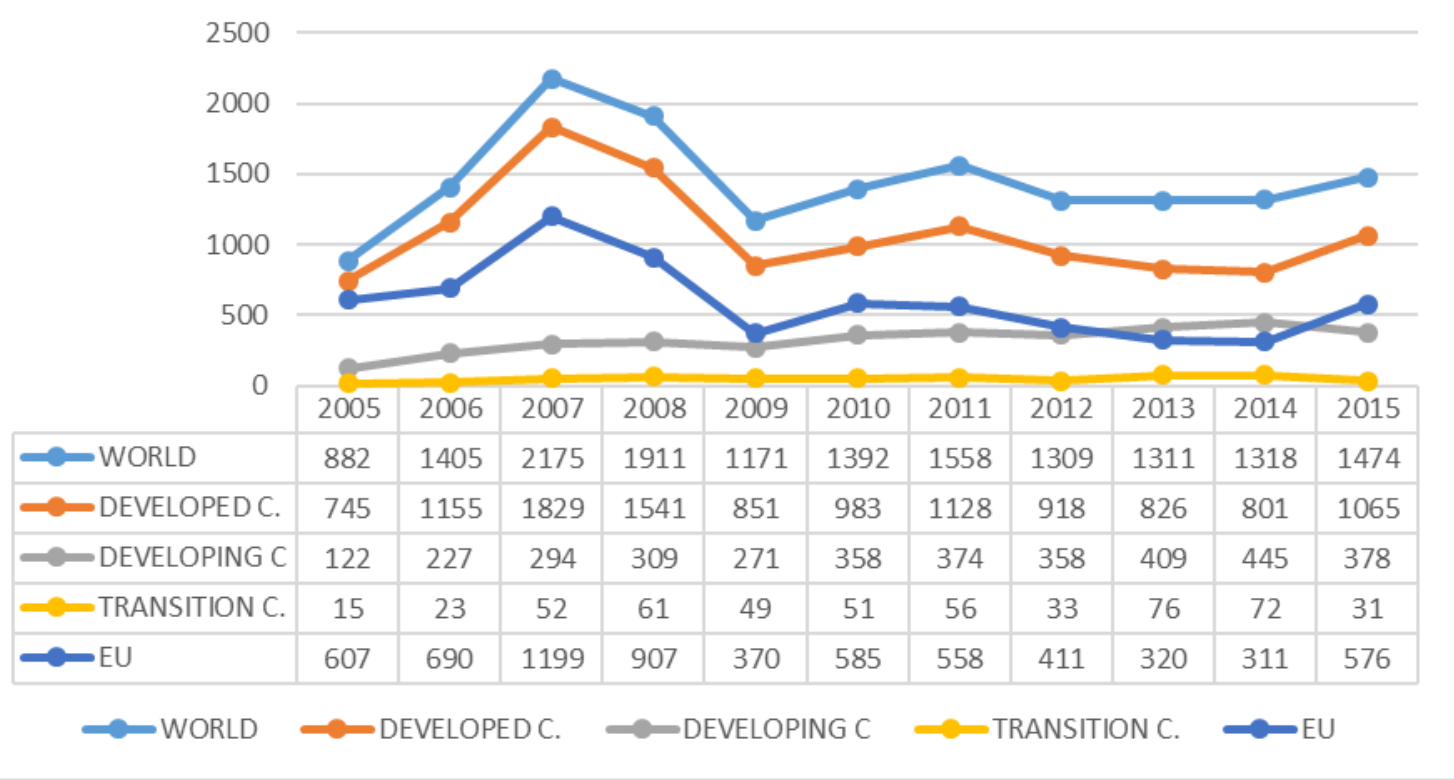

Source: UNCTAD, World Investment Report 2006, 2011 and 2016

Developed Economies have generated the most important part of FDI outflows, over $73 \%$, followed by Developing Economies that are responsible for approx. 23\% of global outward FDI flows from, while transition Economies held a non significant, namely $3.3 \%$ in FDI outflows at global level (see table no.2). 
"Mircea cel Batran" Naval Academy Scientific Bulletin, Volume XX - 2017 - Issue 1 The journal is indexed in: PROQUEST / DOAJ / Crossref / EBSCOhost / INDEX COPERNICUS / DRJI / OAJI I JOURNAL INDEX I I2OR / SCIENCE LIBRARY INDEX / Google Scholar / Academic Keys/ ROAD Open Access I Academic Resources / Scientific Indexing Services / SCIPIO / JIFACTOR

Table 2 Structure of FDI outflows by level of development (average values for 2004-2014)

\begin{tabular}{|l|l|l|}
\hline Level of development & Billions US\$ & $\%$ \\
\hline Developed economies & 1076,55 & 73,93 \\
\hline Developing economies & 322,27 & 22,77 \\
\hline Transition economies & 47,18 & 3,30 \\
\hline Total & 1446,00 & 100 \\
\hline
\end{tabular}

Source: Own calculations based on data presented in UNCTAD World Investment Report 2006, 2012 and 2016

FDI outflows from developed Economies increased constantly until 2007 when it reached maximum volume of outward FDI (Billions US \$ $1,829)$, with $167 \%$ higher than that recorded in 2004. The declining trend since 2008 has resulted in significantly reducing FDI outflows having as source the developed economies, to the level of US \$ 851 Billions in 2009, representing $46.52 \%$ of the amount owed for the year 2007. In the following years, an uptrend of initial investment flows was registered, followed by lower outflows of foreign capital to 801 billion USD in 2014, followed by a spectacular increase of 33 percentage points in the next year, up to 1065 billions USD. In comparison, developing Economies generated constantly increasing FDI outflows with the exception of 2009, when there was a decrease of 38 billions USD.In 2014 foreign capital outflows having as source the Developing Economies peaked a value of US \$ 445 billion, an increase of approximately $265 \%$ compared to 2005 , followed by a decline in FDI outflows in 2015 of 264 billion USD. FDI outflows from Transition Economies have evolved a divergent trend, recording the maximum, US $\$ 76$ billion in 2013. It is noted that compared to 2005, in 2014 outward FDI flows from transition economies increased approximately 4.8 times, but have a dramatic drop of $57 \mathrm{pp}$ in 2015.FDI outflows generated by the EU member states have been oscillated, being USD 576 billion in 2015, 52\% lower than their 2007 peak and lower than the 2005 with 31 billion USD. In the analyzed period the share of EU FDI outflows in total FDI outflows declined from $68.82 \%$ in 2005 to $39,08 \%$ in 2015 , which led to an increasing share in total FDI outflows of Developing Countries by around 12 percentage points in 2005 -2015.Comparative analysis of top 5 countries on FDI outflows shows that the countries values of FDI outflows have a declining trend in 2015 compared to 2007, FDI outflows of the first 5 Countries in 2015 represents $46.07 \%$ of FDI outflows in 2007 . Unlike FDI inflows, it is noted that the structure of countries in the analyzed period has changed radically, the only country that appears in both rankings is Germany.[28]

Table no.3 - Top 5 FDI Outflows Countries 2007 versus 2015

\begin{tabular}{|l|l|l|l|l|}
\hline 2007 & $\begin{array}{l}\text { FDI Outflows } \\
\text { billions USD }\end{array}$ & Rank & 2015 & $\begin{array}{l}\text { FDI Outflows - } \\
\text { billions USD }\end{array}$ \\
\hline UK & 272 & 1 & NETHERLANDS & 113 \\
\hline GERMANY & 171 & 2 & IRELAND & 102 \\
\hline FRANCE & 164 & 3 & GERMANY & 94 \\
\hline SPAIN & 137 & 4 & LUXEMBOURG & 39 \\
\hline ITALY & 96 & 5 & BELGIUM & 39 \\
\hline TOTAL TOP 5 & 840 & ---- & TOTAL TOP 5 & 387 \\
& & & & \\
\hline
\end{tabular}




\begin{abstract}
"Mircea cel Batran" Naval Academy Scientific Bulletin, Volume XX - 2017 - Issue 1
The journal is indexed in: PROQUEST / DOAJ / Crossref / EBSCOhost / INDEX COPERNICUS / DRJI / OAJI I

JOURNAL INDEX I I2OR / SCIENCE LIBRARY INDEX / Google Scholar / Academic Keys/ ROAD Open Access I Academic Resources / Scientific Indexing Services / SCIPIO / JIFACTOR
\end{abstract}

\title{
SOURCE: author computation based on UNCTAD, World Investment Report 2012 and 2016
}

The Netherlands became the largest investor country in Europe, with outflows worth $\$ 113$ billion, followed by Ireland where outflows more than doubled, to $\$ 102$ billion. Germany remained a top investor country, despite its outflows falling by 11 per cent to $\$ 94$ billion. Other major investor countries in Europe were Luxembourg (up 68 per cent to $\$ 39$ billion), Belgium (a more than sixfold increase to $\$ 39$ billion) and France (down 18 per cent to $\$ 35$ billion). The increase in outflows from Switzerland was the largest among developed countries (an increase of $\$ 74$ billion). Ireland occupies a leading position in this ranking, which confirms its economic growth and has become an important source of capital in Europe, ahead of developed European countries, considered as traditional sources of FDI. At EU level, the effects of FDI are materialized by increasing GDP of 12.474 trillion Euro in 2007-13069billions euro in 2013, while external balance of goods and services rose from 69 billion euro in 2007 to 362 billions euro in 2013. [26]

The active population aged 15-64 increased by 4.3 million people in 2007-2013, reaching 237.7 million active people. Of these, people with a job have declined slightly from 228,8 mil to 226,4 mil persons.Labour productivity increased by $3.7 \%$ during 2010-2015, while final consumption registered an upward trend, from 8.985 trillion euros in 2007 to 9262 billions euro in 2013.

\section{Conclusions}

For most of the world economies, FDI has a particular importance, experts opinion being that between FDI and economic growth there is a bidirectional relationship.

Direct investment is an important element of economic development of any country based on the market economy 's principles. Within these, FDI has a particular importance for the integration of national economies into the world economy. FDI contribute to modernizing economies by implementing advanced technologies, know-how's, the new standards by switching to a higher type of growth and international specialization. Investments are a very important source of economic growth because they lead to the expansion of existing capacities, create new capabilities and strengthen the production potential of the economy. Investments in general, and more so the high efficiency ones, promotes technical progress, leading to increased efficiency and a higher rate of growth, as key elements in bridging the gaps. The importance and effects of FDI attracted the attention of all states, leading to a fierce competition to attract capital flows.

\section{Bibliography}

[1]. Alfaro L., Chanda A., Kalemli-Ozcan S., Sayek S. (2006), How does foreign direct investments promote economic growth? Exploring the effects of financial markets on linkages, NBER Working Paper Series, No. 12522.

[2]. Anghel, I., Iancu, A., - Foreign direct investment in Romania, Expert Publishing House, Bucharest, 2002, p. 12.

[3]. Bergstrand, Jeffrey H., 1985. "The Gravity Equation in International Trade: some Microeconomic Foundations and Empirical Evidence," Review of Economics and Statistics, volume 67, number 3, August, 474-481.

[4]. Borensztein, E., De Gregorio J., Lee J.W. (1998), How Does Foreign Direct Investments Affect Economic Growth?, Journal of International Economics, No 45.

[5]. Carkovic M., Levine R. (2002), Does Foreign Direct Investments Accelerate Economic Growth? In: Moran H. T., Graham E., Blomstrom M. (eds.), Does FDI Promote Development?, Institute for International Economics, Washington.

[6]. Chowdhury A., Mavrotas G. (2006), FDI and growth: What causes what? The World Economy, No 29(1).

[7]. Durham, K. B. (2004), Absorptive Capacity and the Effects of Foreign Direct Investments and Equity Foreign Portfolio Investments on Economic Growth, European Economic Review, No 48.

[8]. Eller, Markus, Peter, Haiss and Katharina, Steiner, (2006), Foreign Direct Investment in the Financial Sector and Economic Growth in Central and Eastern Europe: The Crucial Role of the Efficiency Channel, Emerging Markets Review, Vol: 7, pp. 300 - 319;

[9]. Hermes, N. Lensink R. (2003), Foreign Direct Investments, Financial Development and Economic Growth, Journal of Development Studies, No 40.

[10]. Herzer, D., Klasen, S. and Nowak-Lehmann D.F. (2008), In Search of FDI-led Growth in Developing Countries: The Way Forward. Economic Modelling, 25(5), 793-810;

[11]. Iacovoiu, V. - Foreign direct investment between economic theory and practice, Ed. ASE, Bucharest, 2009, p. 45. 


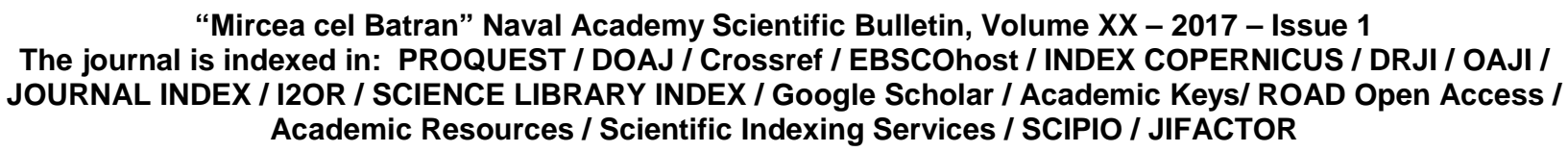

[12]. Kinoshita, Y. and Lu, C.H. (2006), On the Role of Absorptive capacity: FDI Maters to Growth. Working Paper Series no. 845 - William Davidson Institute, University of Michigan Stephen, M. Ross Business School;

[13]. Kottaridi, Constantina and Thanasis, Stengos, (2010), Foreign Direct Investment, Human Capital and Non-Linearities in Economic Growth, Journal of Macroeconomics, Vol: 32, pp. 858-871;

[14]. Krugman Paul and Venables Tony (1995) 'Globalization and the Inequality of Nations', Quarterly Journal of Economics 110: 857-80

[15]. Lai, M., Peng, S. and Bao, Q. (2006), Technology Spillovers, Absorptive Capacity and Economic Growth. China Economic Review, 17(3), 300-320;

[16]. Lee, C.C. and Chang, C.P. (2009), FDI, Financial Development, and Economic Growth: International Evidence. Journal of Applied Economics, 12, 249-271;

[17]. Li, Xiaoying and Xiaming, Liu, (2005), Foreign Direct Investment and Economic Growth: An Increasingly Endogenous Relationship, Wrold Development, Vol: 33, Issue: 3, pp. 393-407;

[18]. Limão, Nuno, and Anthony J. Venables, 2001. "Infrastructure, Geographical Disadvantage, Transport Costs, and Trade, The World Bank Economic Review, volume 15, number 3, 451-479.

[19]. Linnemann, Hans, 1966. An Econometric Study of International Trade Flows. Amsterdam: NorthHolland.

[20]. Rappaport, Jordan. 2000. "How Does Openness to Capital Flows Affect Growth?" Mimeo, Federal Reserve Bank of Kansas City, (June)

[21]. Romer M. (1993), Idea Gaps and Object Gaps in Economic development, JJournal of Monetary Economics. No 32(3).

[22]. Rusu, M, - Foreign Direct Investments, Ed.Paideia, Bucuresti,2000, p. 13

[23]. Scotchmer S. et Thisse J-F., «Les implications de l'espace dans la concurrence», Revue économique, $\mathrm{n}^{\circ} 4,1993$, p. 653-669.

[24].Tinbergen, Jan. 1962. Shaping the World Economy: Suggestions for an International Economic Policy. New York: Twentieth Century Fund.

[25]. Xu, B. (2000), Multinational Enterprises, Technology Diffusion, and Host Country Productivity Growth, Journal of Development Economics, Vol: 62, pp. 477-493;

[26]. Eurostat Statistics, accesed on http://appsso.eurostat.ec.europa.eu/nui/submitViewTableAction.do.

[27]. National Bank of Romania, NBR Report, 2008, p.1

[28].UNCTAD, World Investment Report 2006, 2012 and 2016 accesed on http://unctad.org/en/pages/DIAE/World\%20Investment\%20Report/WIR-Series.aspx

[29]. World Bank Databases, http://data.worldbank.org/indicator/NY.GDP.MKTP.KD.ZG 